\title{
ФЕНОМЕН БАГАТОМОВНОСТІ ТА ЙОГО ОЦІНКА В СУСПІЛЬНО-ПОЛІТИЧНОМУ КОНТЕКСТІ НІМЕЧЧИНИ
}

Гаманюк В. А. Феномен багатомовності та його оцінка в суспільно-політичному контексті Німеччини.

У статті простежується динаміка змін у підходах до оцінки дво- і багатомовності особистості, узагальнено погляди зарубіжних та вітчизняних науковців на феномен двоі багатомовності у контексті суспільно-політичних змін, а також систематизовано наявні класифікації типів багатомовності з урахуванням покладених у їх основу критеріїв.

Ключові слова: мовна ситуація, багатомовність, типи багатомовності, білінгвальне навчання.

Гаманюк В. А. Феномен многоязычия и его оценка в социально-политическом контексте Германии.

В статье прослеживается динамика изменений в подходах к оценке дву- и многоязычия, обобщаются взгляды зарубежных и отечественных ученых на феномен многоязычия в контексте социально-политических изменений, а также систематизированы имеющиеся классификации типов многоязычия с учетом положенных в их основу критериев.

Ключевые слова: языковая ситуация, многоязычие, типы многоязычия, билингвальное обучение.

Hamanyuk V. A. The Phenomenon of Multilingualism and its Evaluation in the Social and Political Context in Germany.

The article traces the dynamics of changes in the approach to the assessment of bi-and multilingualism, summarizes the views of foreign and domestic scientists at the phenomenon of multilingualism in the context of social and political change, as well as a systematic classification of the available types of multilingualism to the situation in their base criteria.

Key words: language situation, multilingualism, the types of multilingualism, bilingual education.

Ознаками сучасного суспільства є багатомовність і полікультурність. Представники різних мовних спільнот перебувають на одній території й контактують між собою. Задля уможливлення безперешкодного спілкування 
постала потреба в розширенні мовного репертуару пересічного громадянина. Розв'язання цієї проблеми покладено на системи іншомовної освіти, насамперед у межах системи шкільної освіти європейських країн має відбуватися навчання двох іноземних мов. У науковому просторі тривають дискусії щодо того, як білінгвізм впливає на розвиток особистості, $\epsilon$ він корисним, шкодить інтелектуальному розвитку чи прискорює його.

До вивчення окресленої проблеми долучилися провідні лінгвісти, педагоги та методисти різних країн, що вивчали питання в національних контекстах. Серед зарубіжних науковців, які долучилися до вивчення проблеми білінгвізму та багатомовності, слід назвати таких, як: Е. Анісфельд, К.-Р. Бауш, С. Бен-Зеев, М. Браун, У. Вайнрайх, А. Вайс, М. Вільдхаге, Г. Клосс, Г. Кріст, В. Ламберт, Ф. Й. Майснер, Е. Оттен, Е. Піл, Т. Скутнаб-Кангас та інші. На пострадянському науковому просторі проблемам білінгвізму приділяли увагу Е. Анафієва, Т. Боднарчук, Е. Верещагін, Н. Дуда, В. Розенцвейг, О. Слоньовська, Ф. Філін, О. Чередніченко, Д. Чубукова, Л. Щерба, А. Ширін.

Мета статті - дослідити динаміку змін у підходах до оцінки багатомовності у науковому просторі та визначити провідні для мовної ситуації ФРН типи дво- та багатомовності 3 огляду на суспільнополітичну складову.

Мовна ситуація в кожній країні відрізняється своїми особливостями, тому питання білінгвізму в публікаціях науковців різних країн має специфічне національне забарвлення. Основними факторами впливу на оцінку двомовності $\epsilon$ : особливості історичного розвитку, структура суспільства та національна й наднаціональна (загальноєвропейська) мовна політика, яка реалізується як у політиці держави щодо державної мови/мов, регіональної мови/мов, мови/мов національних меншин, так і в політиці держави стосовно навчання іноземних мов у системі освіти.

У Німеччині питання двомовності було актуальним завжди. Країна, що протягом віків була розділена на князівства та графства, кожне 3 яких послуговувалося власним діалектом, ще й сьогодні з мовної позиції не $є$ однорідною. Німецька літературна мова $є$ інструментом порозуміння для мешканців різних регіонів як ФРН, так і громадян Австрії, Швейцарії, Люксембургу та Ліхтенштейну. Тож, окрім літературної мови (Hochdeutsch), громадяни цих країн розмовляють ще й одним з багатьох діалектів німецької мови, що теж вважається показником двомовності. Швейцарія і Люксембург узагалі мають кілька державних мов, що спонукає до дво- та багатомовності.

У різні періоди європейської історії одна з європейських мов виконувала функцію lingua franca: латинська, французька, італійська, англійська. Але якщо в минулому лише окремі особи володіли мовою міжєвропейського спілкування, то сьогодні, зважаючи на тотальне домінування англійської мови, двомовність за формулою «рідна мова + англійська» набула масового 
характеру. Тому оцінка феномена білінгвізму, дослідження його позитивного та/або негативного впливу, як i вивчення проблем білінгвального навчання, перебувають у центрі уваги дослідників з різних позицій.

На початку XX ст. у публікаціях йшлося насамперед про негативний вплив білінгвізму. Такі висновки робилися в першу чергу через національнодержавну політику в Свропі, лозунгом якої був «Одна нація - одна мова». Усі публікації того часу мали заполітизований характер, спрямовувалися на створення націоналістичної держави в Німеччини і не грунтувалися на всебічних наукових дослідженнях. Однак ця обставина не завадила твердженням про нібито негативний вплив білінгвізму на особистість залишатися актуальними аж до 70-х років XX століття. Так, Г. Кегель вказував на гальмування інтелектуального розвитку дитини, Дж. Фішман підкреслював, що негативний вплив двомовності виявляється передусім у соціальній сфері, а його показниками є бідність, слабкість, нерезультативність та підпорядковане соціальне становище двомовних осіб. Відповідно, тому, хто мав бажання чогось досягти у професійному, інтелектуальному та соціальному плані, слід було полишити білінгвізм і зосередитися на засвоєнні однієї мови.

Нові дослідження вказують на те, що білінгвальні діти в інтелектуальному розвитку, дивергентному мисленні, у спостережливості й аналізі різних мовних аспектів, з позиції сформованості металінгвістичної свідомості, у сприйнятті невербальних засобів комунікації мають кращі успіхи, аніж монолінгвальні діти.

3 посиленням глобалізації, міграційних процесів та викликаних ними присутністю інших культур у межах колишніх національних держав та зростанням інтересу до інших народів та їх мов, кардинально змінилася не лише думка науковців, але й ставлення пересічних громадян до ідеї білінгвального навчання.

Для розуміння білінгвізму та багатомовності суттєве значення мають поняття «рідна мова» та «двомовність».

«Рідна мова»є складним поняттям. Його детально описує за чотирма критеріями Т. Скутнаб-Кангас у своєму дослідженні, датованому ще 1981 р. «Bilinguism or not». Цими критеріями дослідник вважає: походження, компетентність, практичне використання та ідентифікацію. Дослідження показало, що кожна особа, яка перебуває в полікультурному та мультилінгвальному середовищі, може мати, якщо виходити з названих критеріїв, 2-4 рідні мови. Що стосується ідентифікаційного критерію, то, за Т. СкутнабКангас, можна говорити про внутрішню та зовнішню самоідентифікацію. Внутрішня - ідентифікація особистості як такої, а зовнішня - як частини соціуму, що представляє одну мову. Це свідчить про те, що поняття «рідна мова» $є$ не тільки досить складним для однозначної дефініції, але й може охоплювати в кожному конкретному разі кілька мов.

Білінгвізм як явище вивчали дослідники з різних позицій, існує ๑ В. А. Гаманюк, 2013. 
безліч дефініцій, але жодної всеохоплюючої. Одне 3 перших визначень двомовності запропонував М. Браун ще в першій половині XX ст. Він зазначав: «під багатомовністю розуміється активне, вільне володіння двома або більше мовами на однаковому рівні, без урахування способу оволодіння ними» [9, с. 115].

А. Вайс вважає, що під двомовністю слід розуміти безпосереднє активне та пасивне використання двох мов однією особою [14]. Хоч, на відміну від М. Брауна, А. Вайс обирає показником не володіння, а використання мови, усе ж головним показником є компетентність мовця, а якщо судити за цим критерієм, то однозначно назвати двомовною особу або не назвати іiі такою досить складно. Усе залежатиме від розуміння того, наскільки добре людина має володіти мовою. Інше визначення, але вже багатомовності, наводить Г. Кріст: «... багатомовною може вважатися особа, яка на основі знання своєї рідної мови має обмежені знання як мінімум ще двох мов, які вона здатна використовувати в одній або в різних галузях дискурсу» [8, с. 208].

Для визначення дво- чи багатомовності на сучасному етапі критерії компетентності та функціональності навряд чи можуть відповідати вимогами полілінгвального та мультикультурного суспільства. Сьогодні метою навчання мов є рецептивна або пасивна багатомовність.

Тут постає питання, чи кожна людина здатна бути багатомовною? Наведемо думку Ф. Й. Майснера, який, спираючись на пропоноване генеративною граматикою визначення поняття «компетенції», зазначив, що кожен 3 відповідним навчальним потенціалом до навчання мов, що бере участь у конкретній мовній інтеракції, здатен до засвоєння другої, третьої, четвертої та подальших іноземних мов [11, с. 174-175]. Інший німецький науковець Е. Оксаар наголосив на тому, що сучасні дослідження жодним чином не заперечують спроможність кожного вивчати іноземні мови, більш того, «мова чи мови можуть вивчатися в будь-якому віці і в різний спосіб [13, с. 75]. Сьогодні загальною є думка, що кожна людина може бути дво- чи багатомовною.

Багатомовність у Німеччині знаходить своє відображення в тому, що кожний навчальний заклад розставляє свої власні пріоритети щодо викладання іноземних мов i розширює їх пропозицію за рахунок партнерських мов. Багатомовність шкільної мовної освіти грунтується не стільки на розширенні мовної пропозиції, як на двомовному викладанні дисциплін шкільного курсу, що на наступному етапі шкільної освіти посилюється введенням інших іноземних мов. Ідеться не про поглиблене вивчення іноземних мов, а про зовсім нову пропозицію шкіл для своїх учнів у нових мультилінгвальних умовах навчання. У такому разі учні мають справу 3 так званим «білінгвальним навчанням», що 3 кожним роком набуває в Німеччині все більшої популярності. 
Існує кілька класифікацій дво- та багатомовності, запропонованих як вітчизняними, так і зарубіжними дослідниками, в основу яких покладено різні критерії. Так, У. Вайнрайх за способом засвоєння мови виділяє три типи білінгвізму: складений, координативний та субординативний. Складений білінгвізм виникає в ситуації, коли людина перебуває у двомовному середовищі і засвоює мови у природних умовах на паритетній основі, тобто, наприклад, у двомовних родинах. Координативний білінгвізм розвивається в умовах імміграції, а субординативний - коли система другої мови грунтується на системі першої, тобто в умовах штучного засвоєння мови, наприклад під час навчання [3, с. 22].

В. Розенцвейг пропонує своє розуміння двомовності: «Двомовність (багатомовність) - володіння двома (кількома) мовами, а також регулярне перемикання 3 однієї мови на іншу залежно від ситуації та потреб спілкування» [4, с. 9-10]. С. Верещагін теж виділяє три типи білінгвізму: рецептивний, репродуктивний та продуктивний, а критерієм $є$ рівень впевненого й адекватного використання мови.

Ще одне бачення демонструє Л. Щерба й пропонує розрізняти чистий i змішаний типи двомовності. Під чистим типом він розуміє незалежне існування двох мов у свідомості та у процесі живого спілкування, а під змішаним - ті випадки, коли кожен елемент однієї з мов виявляється пов'язаним за змістом з відповідним елементом іншої.

Ф. Філін, абстрагуючись від психологічних та лінгвістичних аспектів цього явища і зосереджуючись на прагматичних, тобто здатності практичного використання мови, пропонує розглядати білінгвізм у широкому та вузькому розумінні. Двомовність у широкому розумінні - низький рівень знань іноземної мови, але достатній для здійснення комунікації на елементарному рівні, а двомовність у вузькому розумінні - вільне володіння двома мовами, що є результатом засвоєння мов у природних умовах, тобто коли людина постійно перебуває у двомовному середовищі [2, с. 212-214].

Г. Клосс пропонує розглядати національну одномовність, білінгвізм i багатомовність, з одного боку, та індивідуальну одномовність, білінгвізм та багатомовність - 3 іншого [5].

Н. Дуда вказує на відсутність однозначного ставлення до білінгвізму. Розглядаючи це явище з різних позицій, науковці по-різному оцінюють той вплив, який білінгвізм здійснює на особистість та суспільство загалом. Так, соціолінгвістика дає білінгвізму переважно негативну оцінку через те, що двомовна ситуація породжує нестабільність у суспільстві, а психологи вбачають негативний вплив у першу чергу на психіку дитини. Однак, в умовах мультикультурності білінгвізм є позитивним явищем, а двомовна особистість, яка володіє двома засобами мови, володіє і двома способами мислення, а це посилює можливості індивіда, підвищує його інтелектуальний рівень та культуру [5].

(C) В. А. Гаманюк, 2013. 
Розрізняють індивідуальну й масову двомовність. Зазвичай лінгвісти розглядають явище масової двомовності як перехідний етап витіснення однієї мови іншою, тобто в контексті конвергенції. Одним з етапів цього процесу є перетворення білінгвізму в диглосію, під чим розуміють мовну ситуацію, коли в одному суспільстві паралельно використовуються дві мови, але вони виконують різні функції, використовуються у різних обставинах, які не перетинаються, а одна з них є домінуючою [5].

Найбільш поширеними типами двомовності вважається природний i штучний білінгвізм. Перший формується під час постійного спілкування, узаємодії з носіями мови, що вивчається, «без цілеспрямованої дії на становлення двомовного індивіда». Другий тип виникає через цілеспрямоване свідоме засвоєння іншої мови без участі ії носіїв, за словами Л. Щерби, «в умовах відсутності іноземного оточення» [1, с. 137].

Російська дослідниця Д. Чубукова природний білінгвізм називає «контактним», наголошуючи на умові перебування в іншомовному оточенні для його набуття, та підкреслює його стихійний, некерований характер і безсистемне й несвідоме засвоєння. «Неконтактний білінгвізм», за традиційною класифікацією, - штучний білінгвізм [5].

К.- Р. Бауш, грунтуючись на дослідженнях учених різних країн, запропонував власну типологію дво- та багатомовності, поклавши в основу шлях засвоєння мови або ії вивчення. Дослідник виходив з того, що для розробки концепцій навчання іноземних мов слід чітко визначити мету навчання, а для цього необхідно усвідомити специфіку кожного 3 типів багатомовності і спрямовувати зусилля при розробці концепцій на досягнення багатомовності того чи того типу, зважаючи на суспільне замовлення й індивідуальне прагнення громадян. 3 огляду на тип багатомовності слід розробляти і курикулярну модель навчання мови, яка має бути адресною, тобто орієнтуватися на запити певної цільової групи. В основу класифікації типів багатомовності дослідник поклав різні критерії, які, на його думку, є важливими для сфери навчання іноземних мов: критерій рівня загальної мовленнєвої компетенції (globale Sprachfertigkeit), критерій мовленнєвої (individualspezifische) і розумової репрезентації (mentale Repräsentation), критерій вікової співвіднесеності (altersbezogen).

За критерієм рівня загальної мовленнєвої компетенції виділяють такі типи багатомовності: мінімальна (minimale), максимальна (maximale), виважена/паритетна (ausgewogene), або симетрична (symmetrische), домінантна (dominante), або асиметрична (asymmetrische) дво- та багатомовність і семілінгвізм (Semilingualismus).

3 позиції мовленнєвої репрезентації (врахування специфічних для особи індивідуальних характеристик - шлях вивчення / засвоєння мов, комунікативні наміри, порядок вивчення мов, сфера використання тощо) виділяють такі типи: функціональна (funktionale), продуктивна (produktive) 
та рецептивна (rezeptive) дво- та багатомовність.

Критерій розумової репрезентації дає змогу виділити такі типи, як координована (koordinierte) та комбінована (kombinierte) дво- та багатомовність.

Критерій вікової співвіднесеності дозволяє розрізнювати ранній білінгвізм (frühkindlicher Bilingualismus) конзекутивну (konsekutive), або сукцессивну/поступову (sukzessive) дво- та багатомовність [7, с. 440-442].

Ф.- Г. Кьонігс та Г. Нойнер, з огляду на систему освіти, пропонують розрізняти насамперед три основні типи багатомовності: ретроспективну (retrospektive), ретроспективно-проспективну (retrospektiv-prospektive) та проспективну (prospektive) [12, с. 15].

Характеризуючи наявні в педагогічній літературі класифікації типів дво- та багатомовності, С. Дофф і А. Ленц звертають увагу на те, що всі вони не можуть вважатися досконалими, оскільки в їх основу покладено, на думку дослідниць, хибний підхід, специфіка якого полягає в тому, що встановлюється зв'язок між мовленнєвою компетенцією рідної і кожної іноземної мови, а сама компетентність розглядається як статичний, у будьякий момент доступний і відтворюваний мовленнєвий ресурс [10, с. 33].

О. Чередниченко пропонує власну типологію дво- та багатомовності. У iї основу покладено кілька суттєвих ознак, які охоплюють як кількісні, так і якісні сторони цього явища. Дослідник запропонував такі критерії: за ступенем поширення, за ціннісною орієнтацією, за рівнем розмежування мовних систем та за характером комунікативного включення. Тож, відповідно до визначених ним критеріїв, дослідник розрізняє індивідуальну і колективну (масову) двомовність/ багатомовність, горизонтальну (рівнозначність мов 3 позиції мовця) та вертикальну (виокремлення пріоритетних 3 позиції мовця мов, їх нерівнозначність і різновартісність), координативну (чисту) та субординативну (змішану), i, нарешті, активну й пасивну двомовність/ багатомовність. Крім того, автор пропонованої типології зауважує, що на сучасному етапі, «з огляду на необхідність збереження літературних норм контактуючих мов, ідеальним міг би бути тип активної індивідуальної (або колективної) горизонтальної та координативної двомовності/ багатомовності [6]. Однак загальною для будь-якого типу багатомовності, ii найсуттєвішим показником є те, що вона грунтується на прагматизмі.

Отже, суспільно-політична складова, а саме полікультурний характер суспільства, став підгрунтям для дво- і багатомовності громадян більшості країн. Здатність спілкуватися більше ніж однією мовою сьогодні не тільки вітається науковцями та практиками іншомовного навчання, але є суттєвим фактором успішної соціалізації особистості. Тому дослідження феномена дво- та багатомовності перебувають у центрі уваги дослідників різних країн. Потужний поштовх проблема багатомовності отримала наприкінці XX століття через інтенсифікацію інтеграційних процесів у Європі, міграцію населення та прагнення, насамперед молоді, бути мобільними.

(C) В. А. Гаманюк, 2013. 
Більшість наявних на сьогодні типів дво- і багатомовності, хоч $\mathrm{i}$ виявляють певні розбіжності в їх дефініціях, усе ж зводяться до кількох основних типів, в основу яких покладено передусім прагматичний аспект. 3 цієї позиції дво- та багатомовність може бути: рецептивною і продуктивною, індивідуальною й суспільною, координованою та субодинативною. Здебільшого маємо справу з частково сформованими навичками мовлення різними мовами, залежно від індивідуальних потреб і сфери використання мови.

\section{Література}

1. Анафієва Е. Проблеми двомовності і багатомовності в умовах нової мовної ситуації / Е. Анафієва // Наукові записки Кіровоградського державного педагогічного університету ім. В. Винниченка : зб. наук. праць. - 2010. - Вип. 89 (2). - С. 135-139.

2. Боднарчук Т. Моделі білінгвальної освіти у теорії та досвіді діяльності сучасної школи / Т. Боднарчук // Вісник Львівського університету. - 2007. - Вип. 22. - С. 212-219.

3. Вайнрайх У. Языковые контакты: Состояние и проблемы исследования / У. Вайнрайх. - К. : Высшая школа, 1979. - 263 с.

4. Розенцвейг В. Ю. Основные вопросы теории языковых контактов В. Ю. Розенцвейг // Новое в лингвистике : Языковые контакты. - Вип. IV. - М. : Прогресс, 1972. - С. 9-10.

5. Дуда Н. М. Білінгвізм як фактор формування мовної особистості [Електронний pecypc] / Н. М. Дуда. - Режим доступу : http://conf.vstu.vinnica.ua

6. Чередниченко О. Багатомовність і концептуальна картина світу [Електронний pecypc] / O. I. Чередниченко. - Режим доступу : http://www.rius.kiev.ua

7. Bausch K.-R. Überlegungen zu einem integrativen Mehrsprachigkeitskonzept : 14 Thesen zum schulischen Fremdsprachenlernen / K.-R. Bausch, B. Helbig-Reuter // Neusprachliche Mitteilung aus Wissenschaft und Praxis. - 2003. - Jg. 56. - H. 4. - S. 194-201.

8. Bertrand Y. Vorschläge für einen erweiterten Fremdsprachenunterricht / Y. Bertrand, H. Christ // Neusprachliche Mitteilungen. - 1990. - № 43. - S. 208-212.

9. Braun M. Beobachtungen zur Frage der Mehrsprachigkeit / M. Braun // Göttingische Gelehrte Anzeigen. - 1937. - № 4. - S. 115-130.

10. Doff S. Ziele und Voraussetzungen eines fachübergreifenden Fremdsprachenunterrichts am Beispiel von Englisch und Latein / S. Doff, A. Lenz // Pegasus - Onlinezeitschrift. 2011. - Heft I (XI). - S.31 - 49.

11. Meißner F.-J. Umrisse der Mehrsprachigkeitsdidaktik. / F.-J. Meißner / Verstehen und Verständigung durch Sprachenlernen? / [L. S. Bredella]. - Bochum: Universitätsverlag Dr. N. Brockmeyer, 1995. - S. 172-187.

12. Neuner G. Mehrsprachigkeitskonzept und Tertiärsprachendidaktik / G. Neuner / Mehrsprachigkeitskonzept - Tertiärsprachenlernen - Deutsch nach Englisch / [B. Hufeisen, G. Neuner]. - Strasbourg: Europarat, 2003. - 248 S. - S. 13-34.

13. Oksaar E. Psycho- und pädolinguistische Aspekte / E. Oksaar / Spracherwerb des Kindes / [G. Lange, K. Neumann, W. Ziesenis]. - 1986. - S. 67-83.

14. Weiss A. Hauptprobleme der Zweisprachigkeit / A. Weiss. - Heidelberg: Carl Winter Universitätsverlag, 1959. - 214 S. 